\title{
Cut-off Score of Indonesian Version of Sensorimotor History Questionnaire for Preschooler and Soft Sign Cambridge Neurological Inventory against Intelligent Quotient
}

\author{
Siti Aminah Sobana, ${ }^{1}$ Tiara Pramaesya, ${ }^{1}$ Uni Gamayani, ${ }^{1}$ Lisda Amalia, ${ }^{1}$ Suryani Gunadharma, ${ }^{1}$ \\ Andi B. P. Birawa, ${ }^{1,2}$ \\ ${ }^{1}$ Department of Neurology Faculty of Medicine Universitas Padjadjaran/Dr. Hasan Sadikin General Hospital \\ Bandung, Indonesia, ${ }^{2}$ National Brain Centre Hospital, Jakarta, Indonesia
}

\begin{abstract}
Early detection of Sensory Processing Disorder (SPD) is important for deciding on appropriate interventions for children at risk. However, there is no valid screening tool available at this moment. The purpose of this study was to validate the deGangi, Sensorimotor History Questionnaire for Preschooler (SHQP), and neurological soft sign of Cambridge Neurological Inventory (NSS CNI) against intelligent quotient (IQ) to establish a reliable cutoff for SPD screening tools for children aged 4-6 years. Sixty-four parent-child were recruited randomly from 3 kindergartens in Bandung, Indonesia. Eligible parents were asked to fill out the SHQP, while their child was assessed using theWechsler Preschool and Primary Scale of Intelligent (WPPSI) and NSS CNI. The deGangi SHQP score and NSS CNI showed a weak and moderate correlation with Full-scale IQ (FIQ). The total score of deGangi SHQP's sensitivity was $50 \%$ with a specificity of $53.4 \%$ and a negative predictive value (NPV) of $91.2 \%$ agaisnt the FIQ score. The total sensitivity for the NSS CNI was $66.7 \%$, while the total specificity was $58.6 \%$ and the NPV was $94.4 \%$. Meanwhile, the sensitivity for the sensory integration subscale score of the NSS CNI was $83.3 \%$, with a specificity of $60.3 \%$ and an NPV of $97.2 \%$. The deGangi SHQP can be considered to be an SPD screening tool with the cut-off scores for each subscale of self-regulation, sensory processing of touch, sensory processing of movement, emotional maturity, and motor maturity of 3,3,3, and 2, respectively, while the NSS CNI can be used for identifying SPD in children aged 4-6 years with a cut-off scores for the motor coordination, sensory integration, and disinhibition subscales of 7, 10, and 3, respectively.
\end{abstract}

Keywords: Neurological soft sign, sensorimotor questionnaire, sensory processing disorder, validation

\section{Skor Ambang Batas versi Bahasa Indonesia dari Sensorimotor History Questionnaire for Preschooler dan Soft Sign Cambridge Neurological Inventory terhadap Tes Intelligent Quotient}

\begin{abstract}
Abstrak
Deteksi awal gejala Sensory Processing Disorder (SPD) merupakan hal yang penting agar dapat segera mendapat intervensi dengan tepat. Instrumen yang valid diperlukan untuk mendeteksi anak dengan gejala SPD. Tujuan penelitian ini adalah memvalidasi instrumen deGangi Sensorimotor History Questionnaire for Preschooler (SHQP) dan neurological soft sign Cambridge Neurological Inventory (NSS CNI) terhadap tes Intelligent Quotient (IQ) dan menentukan nilai titik potong yang dapat diandalkan sebagai alat penapisan SPD pada anak usia 4-6 tahun. Enam puluh empat anak dari 3 Taman Kanak-kanak di Kota Bandung dipilih secara acak sederhana untuk ikut serta pada penelitian ini. Orangtua sampel terpilih mengisi deGangi SHQP versi Bahasa Indonesia. Anak terpilih dilakukan pemeriksaan tes IQ dengan metode Wechsler Preschool and Primary Scale of Intelligent (WPPSI) dan pemeriksaan NSS CNI. Skor deGangi SHQP dan NSS CNI berkorelasi lemah dan sedang terhadap skor Full IQ (FIQ). Total skor deGangi SHQP memiliki sensitivitas 50\%, spesifisitas 53,4\%, dan nilai prediksi negatif (NPN) 91,2\% terhadap FIQ. Total skor NSS CNI memiliki sensitivitas 66,7\%, spesifisitas 58,6\%, dan NPN 94,4\%. Subtes integrasi sensorik pada NSS CNI memiliki sensitivitas 83,3\%, spesifisitas 60,3\%, dan NPN 97,2\%. Instrumen deGangi SHQP dapat dipertimbangkan sebagai alat penapisan SPD dengan nilai titik potong untuk tiap-tiap subskala kemampuan regulasi diri, pemrosesan sensori taktil, pemrosesan sensori gerakan, kematangan emosional dan kemampuan motorik, yaitu 3, 3, 3, 3, dan 2. NSS CNI dapat digunakan untuk mengidentifikasi SPD pada anak usia 4-6 tahun dengan nilai titik potong untuk subskala koordinasi motorik, integrasi sensori, dan disinhibisi, yaitu 7, 10, dan 3.
\end{abstract}

Kata kunci: Kuesioner sensorimotor, neurological soft sign, sensory processing disorder, validasi

Corresponding author: Siti Aminah Sobana, Department of Neurology, Faculty of Medicine Universitas Padjadjaran/Dr. Hasan Sadikin General Hospital, Jl. Pasteur No. 38 Bandung, West Java, Indonesia, Email: aminahdr@yahoo.co.id 


\section{Introduction}

A significant developmental milestone in childhood is the transition from preschool to formal elementary school education. Many factors contribute to the readiness of a child for school. Factors that negatively influence children's success in school include their age, socioeconomic status, and their ability to interpret sensory information from their environment. The ability to regulate incoming and outgoing sensory information sets up for success in their academic pursuits. ${ }^{3}$

Sensory Processing Disorder (SPD) is a condition in which an individual has significant difficulty detecting, modulating, discriminating, integrating, or responding to sensoryinformation in one or more of the eight sensory systems. The sensory systems include 5 basic senses, vestibular, proprioception, and interoception. The SPD diagnosis is applicable when a person has significantly unusual or atypical behavioral responses to sensory stimuli that are reflected in emotion, attention, or motor responses to sensory input. Inappropriate sensory responses must result in consistent, functional impairments in daily activities and routines at school, at home, and/or in the community. ${ }^{1}$ Modulation and processing of the range of sensory experiences allows one to social engagement and attachment to others. A child who is easily overwhelmed by sounds, touch, movements, or visual stimulation may avoid interactions with persons or situations that are highly stimulating. In contrast, the child who does not process sensory input, unless it is very intense, may develop a pattern of thrill seeking, high stimulation, and risky behavior. ${ }^{2}$ Children with SPD may face greater challenges with the demands of school/kindergarten. ${ }^{3}$

Earlier detection and management of sensory processing problems can play an important role for the performance improvement in children. Early assessment of sensory-motor skills is suggested to be used for the prediction of academic performance deficits. There are no formal diagnostic criteria for children experiences SPD. Sensory problems are usually assessed using parents or caregivers reported questionnaires. The Sensorimotor History Questionnaire for Preschooler (SHQP) was used to provide information about the child's sensory processing. ${ }^{4,5}$

A study has centered on a subset of abnormalities in both sensory and motor processes (often called "neurological soft signs [NSS]") and has found them to be predictive of negative outcome. Children with higher scores on the soft sign battery had worse performance on measures of cognition, coordination and behavior. ${ }^{6}$ The Cambridge Neurological Inventory (CNI) is a clinical instrument for assessment of soft neurologic signs, and it consisted of three subscales: the motor coordination, sensory integration, and disinhibition. ${ }^{7}$

The purpose of the current study is to determine the cut-off score of the SHQP and NSS CNI against intelligent quotient (IQ) in preschooler population in order to establish a reliable cut-off for screening purposes.

\section{Methods}

Sampling begins with the selection of TK. From the city of Bandung, there were 44 kindergartens with an A accreditation, 376 with $\mathrm{B}$ accreditation, and 266 with $\mathrm{C}$ accreditation. Then, one kindergarten was randomly selected with $\mathrm{A}, \mathrm{B}$, and $\mathrm{C}$ accreditation scores. A total of 64 children ( 32 boys and 32 girls) was randomly chosen by simple random sampling from 3 different kindergartens in Bandung city with inclusion criteria: (1) aged 4 to 6 years 6 months, normal growth and development in accordance with the tables of height and weight of Indonesia; (2) no neurological deficits; (3) no history of chronic diseases, such as epilepsy, heart disease, diabetes, malignancy, autism spectrum disorder (ASD), attention-deficit hiperactivity disorder (ADHD). We exclude students who were unable to attend or unwilling to be examined. Based on age, the children were divided into 2 groups: 4 to 5 years 6 months ( 32 children) and 5 years 7 months to 6 years 6 months (32 children).

We performed NSS examination and IQ test to the children and SHQP instrument from parents. We analyzed cutt of point of each test.

Screening for SPD can be completed using parent- or teacher-report scales such as the sensorimotor history questionnaire for preschooler (SHQP). The questionnaire has been validated by original author on 3 to 5 years olds as well. Cut-off scores were derived for the SHQP through data collection on children who were normally functioning and those with confirmed sensory-integrative dysfunction using the deGangi-Berk Test of Sensory Integration. This questionnaire was designed to collect the symptoms of SPD in children's daily activity. The SHQP consists of five subscales: self regulation (6 items), sensory processing of touch (9 items), sensory processing of movement (11 items), 
emotional maturity (10 items), and motor maturity (15 items). All parents of the children were asked to complete the SHQP to assess sensory problems and deviant behaviour of their children. The answer were 'yes' or 'no'. Each items is scored 0 or 1 ; high scores indicate more symptoms of SPD. ${ }^{2,5}$

The soft sign subscales of the Cambridge Neurological Inventory (CNI) were used to evaluate neurological soft signs. The CNI has been validated in both healthy individuals and clinical groups with schizophrenia. A total of 250 Chinese schizophrenic patients and 90 normal controls were recruited. A cut-off of 4 in total soft signs yields a sensitivity of 0.63 and specificity of 0.71; Extended assessment battery of CNI provides even better discrimination of patients from normal controls, and soft signs are more strongly associated with schizophrenia than are hard signs in the Chinese sample.

It has three subscales for soft signs: motor coordination (MC; finger tapping, repetitive finger thumb opposition, pronation and supernation, fist-edge-palm), sensory integration (SI; finger agnosia, agraphesthesia, astereognosis), and disinhibition (DI; mirror movements, eye blink or head movement while performing eye tracking). All items were rated by researcher. Ratings were standardized where appropriate to indicate normal response (0), abnormal response (1), and grossly abnormal response (2). ${ }^{8}$

All children were tested using the Wechsler Preschool and Primary Scale of Intelligence (WPPSI).The WPPSI is commonly used to measure intelligence in children aged 3 to 7 years 3 months. It provides 12 subtest scores and 3 composite scores that represents verbal, performance, full- scale IQ (FIQ), and original IQ (OIQ). Five of the six verbal subtests (information, similarities, vocabulary, comprehension, arithmetic, digit, or sentence memory) were used to establish verbal IQ (VIQ), and five of the six non-verbal subtests (picture completion, block design, object assembly, geometric drawing, labyrinths, picture arrangement, animal chequers, or coding) were used to establish performance IQ (PIQ). ${ }^{9}$

Data were analyzed using SPSS for Windows. The association of two instruments's total scores (the SHQP and NSS CNI) with IQ score subscales and age were assessed using a Spearman's test of correlation. A receiver operating characteristic (ROC) curve was calculated for prediction of SPD. The area under the ROC curve (AUC) and an optimal cut-off value were calculated for the total score and each subcscales of the instruments. Standard error for the optimal cut-off value was assessed with bootstrap method. $P<0.05$ was regarded as a statistically significant result. The sensitivity, the specificity, the positive and negative predictive value was also presented.

The study was approved by the research ethics committee of Universitas Padjadjaran, Indonesia No. 28/UN6.KEP/EC/2020.

\section{Results}

A total of 64 children-parent pairs were conducted for the study. Fifty percent was boys. Fifty percent was 4 years- 5 years 6 months. The average height was $17.64 \pm 3.63$; weight 1.09 \pm 0.06 ; and head circumference was $50.59 \pm 1.53 .4 / 64(6.3 \%)$ was preterm and $4 / 64(6.3 \%)$ had low birth weight. $70.3 \%$ of the

Table 1 Mean Values the SHQP Instrument, NSS CNI and its Subscale $(n=64)$

\begin{tabular}{lcc}
\hline \multicolumn{1}{c}{ Variable } & Mean \pm SD Subject & Origin Score \\
\hline The SHQP total score & $11.16 \pm 4.83$ & $0-2$ \\
Self regulation & $2.98 \pm 1.67$ & $0-2$ \\
Sensory processing of touch & $2.23 \pm 1.33$ & $0-2$ \\
Sensory processing of movement & $2.16 \pm 1.28$ & $0-2$ \\
Emotional maturity & $1.78 \pm 1.43$ & $0-3$ \\
Motor maturity & $2 \pm 1.72$ & \\
NSS CNI total score & $32.64 \pm 13.04$ & \\
Motor coordination & $6.84 \pm 3.93$ & \\
Sensory integration & $8.20 \pm 3.16$ & \\
Disinhibition & $2.55 \pm 1.48$ & \\
\hline
\end{tabular}


Table 2 Mean Value of IQ Score

\begin{tabular}{lccc}
\hline & Subject (n) & $\%$ & Score Mean \pm SD \\
\hline Original IQ & 2 & 03.01 & $107.31 \pm 12.43$ \\
$\quad$ Low & 62 & 96.09 .00 & \\
Normal & & & $103.28 \pm 10.44$ \\
Full IQ & 6 & 09.04 & \\
Low & 58 & 90.06 .00 & \\
Normal & & & \\
Verbal IQ & 14 & 21.09 & \\
Low & 50 & 78.01 .00 & $106.48 \pm 12.33$ \\
Normal & & & \\
Performance IQ & 5 & 07.08 & \\
Low & 59 & 92.02 .00 & \\
$\quad$ Normal & & & \\
\hline
\end{tabular}

participants' father and $73.4 \%$ of the mothers, received education beyond a high school diploma. SHQP, NSS CNI showed normal distribution.

Table 1 presents descriptive statistics for the SHQP scores, NSS CNI, and their subscales. The SHQP score on the subject looks not much different from the original SHQP score.

Most of the subjects had normal origin IQ, full IQ, verbal IQ, and performance IQ. But we found that verbal IQ showed the lower score of IQ subtest. Full IQ decrease 4 point compared to

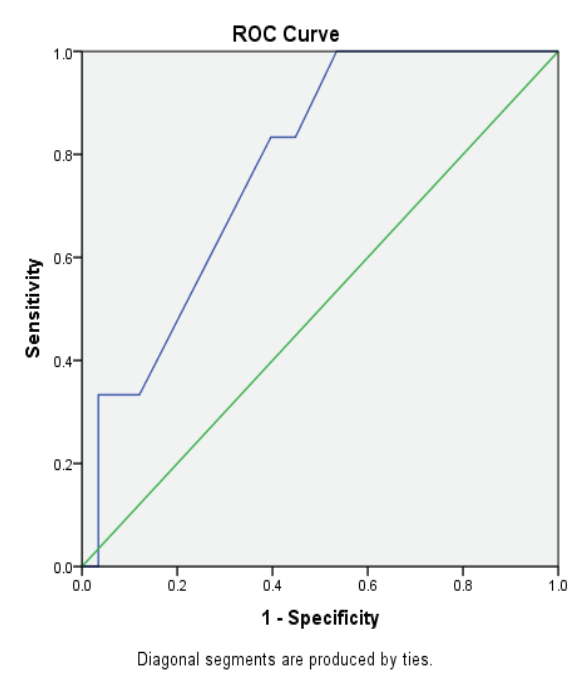

\footnotetext{
Figure Receiver Operating Characteristic Curve (ROC) of Sensory Integration Subscale NSS CNI
}

origin IQ.

This study found significant weak negative correlation between the total score of SHQP and FIQ score $(r=-0.279, p=0.026)$. The total score of NSS CNI showed significant negative correlation with age, FIQ, VIQ, and PIQ scores. Whereas age and FIQ score were moderately correlated with the total score of NSS CNI ( $\mathrm{r}=-0.45$ and -0.428 , $\mathrm{p}<0.001$ ), VIQ and PIQ scores were more weakly correlated with the total score of NSS CNI ( $\mathrm{r}=-$ 0.281 and $-0.393, p=0.025$ and 0.001 ).

For subsequent analysis, we therefore decided to focus on Full-scale IQ (FIQ), because it had the strongest correlation with both instruments.

Diagnostic use of the SHQP and NSS CNI were determined by construction of ROC curves. The total score and subscale scores of both instruments were used as independent variables to determine the best cut-off for discrimination between children with SPD and those FIQ scores within or above the normal range.

The total score of SHQP produced an AUC value of $57.3 \%$, whereas the total score of NSS CNI produced optimal AUC value of $70.5 \%$. The largest AUC value resulted from sensory integration subscale (77.7\%).

For outcome measurement it is important to optimize sensitivity (the proportion of children with SPD correctly identified by the SHQP and NSS CNI) and specificity (the proportion of children without SPD correctly detected by the SHQP and NSS CNI). To this end, the optimal cutoff score for total score of SHQP for identifying an 
SA Sobana et al: Cut-off Score of the Indonesian Version of Sensorimotor History Questionnaire for Preschooler

Table 3 Correlation between the Total Score of SHQP with Age and IQ Scores, and Total Score of NSS CNI with Age and IQ Scores

\begin{tabular}{lcccc}
\hline \multirow{2}{*}{ Test } & \multicolumn{2}{c}{ SHQP } & \multicolumn{2}{c}{ NSS CNI } \\
\cline { 2 - 5 } & $\mathbf{r}$ & P value $^{* *}$ & $\mathbf{r}$ & P value $^{* *}$ \\
\hline Original IQ (OIQ) & -0.143 & 0.261 & -0.236 & 0.061 \\
Full IQ (FIQ) & -0.279 & 0.026 & -0.428 & $<0.001$ \\
Verbal IQ (VIQ) & -0.231 & 0.091 & -0.281 & 0.025 \\
Performance IQ (PIQ) & -0.239 & 0.058 & -0.393 & 0.001 \\
Age & -0.161 & 0.204 & -0.450 & $<0.001$ \\
\hline
\end{tabular}

***Spearman's correlation test

SPD was 12 , and the cut-off score for its subscales were self regulation 3 , sensory processing of touch 3 , sensory processing of movement 3 , emotional maturity 3 , and motor maturity 2 . The optimal cut-off score for total score of NSS CNI for identifying an SPD was 35, and the cut-off score for its subscales were motor coordination 7 , sensory integration 10 , and disinhibition 3 .

This produced sensitivity of $50 \%$, specificity $53.4 \%$, positive predictive value (PPV) $10 \%$, and negative predictive value (NPV) $91.2 \%$ when comparing the total score of SHQP using cut-off score 12 with FIQ $(<90)$.

The total score of NSS CNI sensitivity was $66.7 \%$, specificity was $58.6 \%$, PPV and NPV were $14.3 \%$ and $94.4 \%$ respectively, when using cutoff score 35 and comparing with FIQ $(<90)$. Of the sensory integration subscale of NSS CNI, sensitivity was $83.3 \%$, specificity $60.3 \%$, PPV and NPV were $17.9 \%$ and 97.2 respectively,

Table 4 AUC Values and Cut-off Scores of the SHQP \& NSS CNI

\begin{tabular}{lcc}
\hline Variable & AUC & $\begin{array}{c}\text { Cut-off } \\
\text { point }\end{array}$ \\
\hline The SHQP total score & $57.3 \%$ & 12 \\
Self regulation & $47.8 \%$ & 3 \\
Sensory processing of touch & $60.9 \%$ & 3 \\
Sensory processing of & $50.3 \%$ & 3 \\
movement & $56.9 \%$ & 3 \\
Emotional maturity & $64.5 \%$ & 2 \\
Motor maturity & $70.5 \%$ & 35 \\
The NSS CNI total score & $63.2 \%$ & 7 \\
Motor coordination & $77.7 \%$ & 10 \\
Sensory integration & $58.3 \%$ & 3 \\
Disinhibition &
\end{tabular}

when comparing its score using cut-off score 10 with FIQ $(<90)$.

\section{Discussion}

Cut off point of SHQP total score in children 4-6 years in our study is higher than performed by de Gangi in 36 month old of age. Sensory processing of touch had the higher AUC $(60,9 \%)$. Cut of point of NSS CNI total score compared to full IQ has $70,5 \%$ AUC with cut off point 35 . Sensory integration has a higher AUC $(77,7 \%)$ with cut off point 10.

Mean total SHQP score in this study was 11.16 \pm 4.83 , higher than deGangi's finding in 36 month-old children, which was $7.7 \pm 1.7$. This is might due to age difference and also number of population. Other cause might be to cultural and racial background as deGangi has also mention (personal communication). ${ }^{5}$

Mean total NSS CNI score in this study was $32.64 \pm 13.04$, with wide distribution, a range of 11-86. Mean of each subscale were $6.84 \pm 3.93, \quad 8.20 \pm 3.16$ and $2.55 \pm 1.48$, for motor coordination, sensory integration, and disinhibition respectively. Unfortunately, there is no study in children aged 4-6 years using the NSS CNI instrument yet, for comparison. Chan et al enrolled children with wide range, aged 3-14 years old, so no wonder that the mean NSS CNI values obtained were very much different. Means from Chan's study were 1.86, 2.72, and 0, 71 for motor coordination, sensory integration, and disinhibition respectively. Other finding, the result shows a trend where the older the age, the lower the NSS value. ${ }^{8}$

NSS examination shows motor coordination subscale Oseretski test was the highest with mean value of $1.22 \pm 0.84$, left hand palm fistedge test $1.11 \pm 0.78$, and right hand fist-edge- 


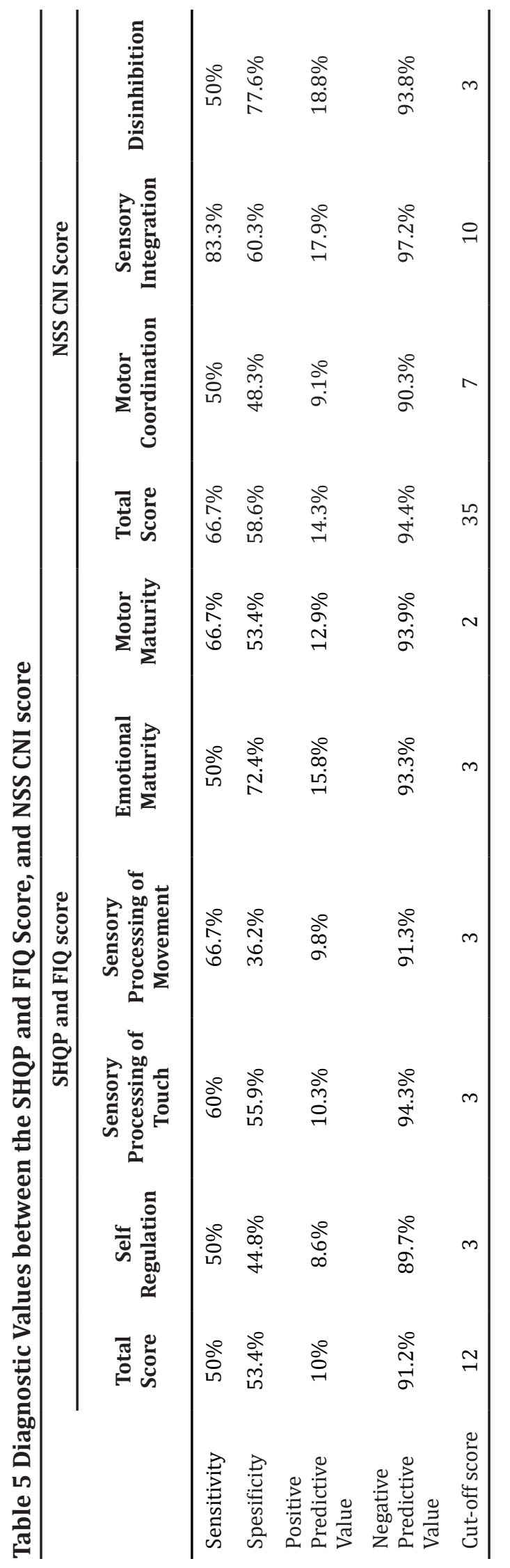


palm test $1.02 \pm 0.85$. Oseretski test or reciprocal coordination test is an examination to find out the function of motor dynamics, by making a fist on one side of the hand and the palm of the other hand in an open state, these movements are carried out together and alternately on both hands. While the fist-edge palm test is an examination carried out by asking the subject to make 3 consecutive movements on one side of the hand. Difficulties in conducting this test indicate impairment or immaturity of the cerebral premotor. ${ }^{10}$

In the sensory integration subscale, the highest mean value was obtained from the examination of right-left orientation, which the mean value was $1.77 \pm 0.58$. The ability to accurately discriminate between right and left body parts will develop with age. Generally, children can distinguish right and left side right at the age of 7 years. ${ }^{10}$ Difficulties encountered in sensory integration examination have a relationship to motor learning disorders, academic ability, attention, and behavior. ${ }^{11}$

In the disinhibition subscale, the highest mean value was go/no-go stimuli examination with mean $0.63 \pm 0.9$. Disinhibition disorders associated with executive function deficits are often shown with symptoms of aggressive behavior in children. ${ }^{12}$ In a study by Mehnert et al, children aged 4 to 6 years, a process of brain maturation in the fronto-parietal lobe playing a role important in cognitive development of inhibition responses. ${ }^{13}$

The mean IQ values findings in this study were $107.31 \pm 12.43$ for OIQ $103.28 \pm 10.44$ for FIQ, $99.97 \pm 11.45$ for VIQ and 106.48 \pm 12.33 for PIQ. This value was almost the same as the 4-6 years age group in a study conducted by Chan which was $103 \pm 9.1$. A handful subject was categorized having a low IQ. There was 3.1\% of subjects classified as having a low OIQ, 9.4\% low FIQ, 21.9\% low VIQ and 7.8\% low PIQ.

Correlation coefficient test for the total NSS CNI score found a significant negative moderate correlation was found to score FIQ ( $\mathrm{r}-0.428, \mathrm{p}$ $<0.001)$ and age ( $\mathrm{r}-0.450, \mathrm{p}<0.001)$, while for VIQ and PIQ scores a negative weak correlation was found. However, no correlation was found between the NSS CNI score and OIQ. In a study by Fellick et al, they found a significant correlation in subjects with low IQ scores (Verbal IQ, Performance, and Total IQ) and higher NSS score. $^{15}$

In this study, the SHQP and NSS CNI instruments were performed with an SPD diagnostic test on FIQ, as the gold standard, for it has the best correlation value. In a study by Crane, low non-verbal IQ scores were associated with more severe sensory impairments. In FIQ scale, we found a weak correlation with sensory disturbance. Whereas with the VIQ scale there was no correlation. ${ }^{16}$

ROC test of the SHQP instrument was evaluated against FIQ, an AUC score of $57.3 \%$ was obtained for the total score with a cut-off 12 . The ROC subscales SHQP test for the FIQ obtained an AUC value for self regulation, sensory processing of touch, sensory processing of movement, emotional maturity, and motor maturity $47.8 \%$, $60.9 \%, 50.3 \%, 56.9 \%$, and $64.5 \%$ with the cutoff scores of 3, 3, 3, 3, and 2, respectively. These cut-off scores are comparable to the original version of SHQP on the self regulation, sensory processing of touch, sensory processing of movements, and emotional maturity. Whereas in motor maturity subscale, deGangi has a different cut-off point, which was 4, higher than our finding.

The total diagnostic test of SHQP against FIQ has a cut-off of 12 in this study, with a sensitivity of $50 \%$ and a specificity of $53.4 \%$. These results illustrate that the SHQP instrument is less adequate to be used as a SPD screening tool. However, the NPV was $91.2 \%$, it showed this instrument is good in excluding healthy subject from an SPD suspicion. Unfortunately, there were no study that has validated this questionnaire before.

Another instrument that is widely used in diagnosing SPD is the Sensory Profile, but this instrument can only be done by trained professionals, hence cannot be used as an initial screening tool at the school level or primary health care by the teacher or general practitioner. Eeles et al conducted a study to evaluate good instruments in identifying SPD. The study evaluated 3 instruments (Sensory Rating Scale, Infant/Toddler Sensory Profile, and the Test of Sensory Function in Infants) and found that it had low to sufficient reliability. ${ }^{17}$ Validity test conducted by Brown against 2 SPD screening instruments, Sensory Profile and Sensory Processing Measure, showed that both instruments has sufficient convergent validity level..$^{18}$ In contrast to Benjamin's research in India which validated the Sensory Profile Caregiver Questionnaire, that shows quite good validity in identifying SPD. ${ }^{19}$

We analyzed NSS CNI on FIQ, we found that the AUC value was $70.5 \%$ for the total score with a cut-off of 35 . The ROC test of the subscale against the FIQ obtained the AUC value for 
motor coordination, sensory integration, and disinhibition were $63.2 \%, 77.7 \%$ and $58.3 \%$, respectively. From this AUC value the quality of diagnostic tests was interpreted good in the sensory integration subscale. The cut-off were 7,10 , and 3 . The cut-off score for the NSS CNI instrument have not yet been determined before in children subject.

We then analyzed NSS CNI on FIQ. The cutoff was 35 with sensitivity of $66.7 \%$, specificity 58.6\%, PPV 14.3\%, and NPV 94.4\%.

For the sensory integration subscale, we found the cut-off was 10 , sensitivity of $83.3 \%$, specificity $60.3 \%$, PPV 17.9\%, and NPV 97.2\%. This showed that sensory integration subscale of NSS CNI has a good diagnostic value for SPD at the age of 4-6 years.

This study has several limitations, first, the number of confounding variables that can affect research results. Confounding variables which were not analyzed in this study include the level of parental education that is very likely to influence parents in interpreting the questions in the questionnaire, the socioeconomic level of the family, and also parenting.

DeGangi SHQP instruments are a reliable instrument to be used by primary health doctors, teachers or any other figure. However, there are not so many study that used the DeGangi SHQP instruments, that used in this study. The more widely used screening instrument is Sensory Profile, this instrument is robust, but can only be utilized by trained professionals, making it difficult to apply to primary health care or by teachers in kindergarten to recognize the initial symptoms of SPD.

The SHQP instrument can be considered to be an SPD screening tool for children aged 4-6 years with a cut-off scores of 12 for total score and cutoff scores for each subscales of self-regulation, sensory processing of touch, sensory processing of movement, emotional maturity, and motor maturity, were $3,3,3,3$, and 2 , respectively.

The NSS CNI examination can be used as a SPD diagnostic tool in children aged 4-6 years with a cut-off score of 35 for total score, and the cut-off score of motor coordination, sensory integration, and disinhibition subscales were 7 , 10 , and 3 , respectively.

\section{References}

1. Carter A, DelCarmen-Wiggins R. The Oxford handbook of infant, toddler, and preschool mental health assessment. $2^{\text {nd }}$ ed. New York:
Oxford University Press; 2019.

2. DeGangi G. Pediatric disorders of regulation in affect and behavior, 2nd Edition. $2^{\text {nd }}$ ed. San Diego: Academic Press; 2017.

3. Boyd LA, Sobieraj SL, Shannon L. Kindergarten Readiness: the impact of sensory integration on preschool children's readiness for the transition to kindergarten. 2013. Graduate Master's Theses, Capstones, and Culminating Projects. 80. Available from: https://doi.org/10.33015/dominican. edu/2013.0T.05.

4. Ghanizadeh A. Sensory processing problems in children with ADHD, a systematic review. Psychiatry Investig. 2011;8(2):8994.

5. DeGangi G, Breinbauer C, Roosevelt J, Porges S, Greenspan S. Prediction of childhood problems at three years in children experiencing disorders of regulation during infancy. Infant Ment Health J. 2000;21(3):156-75.

6. Levit-Binnun N, Golland Y. Finding behavioral and network indicators of brain vulnerability. Front Hum Neurosci. 2012;6:10.

7. Wang X, Cai L, Li L, Yang Y, Yao S, Zhu $X$. Neurological soft signs in Chinese adolescents with antisocial personality traits. Psychiatry Res. 2016;243:143-6.

8. Chan RC, McAlonan GM, Yang B, Lin L, Shum D, Manschreck TC. Prevalence of neurological soft signs and their neuropsychological correlates in typically developing Chinese children and Chinese children with ADHD. Dev Neuropsychol. 2010;35(6):698711.

9. Wahlstrom D, Breaux KC, Zhu J, Weiss LG. The Wechsler Preschool and Primary Scale of Intelligence-Third Edition, the Wechsler Intelligence Scale for ChildrenFourth Edition, and the Wechsler Individual Achievement Test-Third Edition. In: Contemporary Intellectual Assessment: Theories, Tests, and Issues, 3rd ed. New York, NY, US: The Guilford Press; 2012. p. 224-8.

10. Baron I. Neuropsychological evaluation of the child. 2nd ed. New York, NY: Oxford University Press; 2018.

11. Aziz AA, El Sheikh MM, Mohsen NM. Neurological soft signs in a sample of Egyptian ADHD children and their clinical correlates. Middle East Current Psychiatry. 2016;23(2):51-5.

12. Riccio CA, Hewitt LL, Blake JJ. Relation of measures of executive function to aggressive 
behavior in children. Appl Neuropsychol. 2011;18(1):1-10.

13. Mehnert J, Akhrif A, Telkemeyer S, Rossi S, Schmitz CH, Steinbrink J, Wartenburger I, et al. Developmental changes in brain activation and functional connectivity during response inhibition in the early childhood brain. Brain Dev. 2013;35(10):894-904.

14. Takayama Y, Hashimoto R, Tani M, ., Kanai C, Yamada T, Watanabe $\mathrm{H}$, et.al. Standardization of Japanese version of the Glasgow Sensory Questionnaire (GSG). Res Autism Spectrum Disorders. 2014;8:347-53.

15. Pitzianti M, D'Agati E, Casarelli L, Pontis M, Kaunzinger I, Lange KW, et al. Neurological soft signs are associated with attentional dysfunction in children with attention deficit hyperactivity disorder. Cogn Neuropsychiatry. 2016;21(6):475-93.

16. Sanz-Cervera P, Pastor-Cerezuela G, Fermandez-Andres M, Tarraga-Minguez R. Sensory processing in children with autism spectrum disorder: relationship with non-verbal iq, autism severity and attention deficit/hyperactivity disorder symptomatology. Res Dev Disabil. 2015;4546:188-201.

17. Eeles AL, Spittle AJ, Anderson PJ, Brown $\mathrm{N}$, Lee KJ, Boyd RN, et al. Assessments of sensory processing in infants: a systematic review. Dev Med Child Neurol. 2013;55(4):314-26.

18. Brown T, Morrison IC, Stagnitti K. The convergent validity of two sensory processing scales used with school-age children: comparing the sensory profile and sensory processing measure. New Zealand J Occupat Ther. 2010; 57(2):56-65.

19. Benjamin TE, Crasta JE, Suresh AP, Alwinesh MJ, Kanniappan G, Padankatti SM, et al. Sensory profile caregiver questionnaire: a measure for sensory impairment among children with developmental disabilities in India. Indian J Pediatr. 2014;(81 Suppl 2):S183-6. 